\title{
Agresiones a mujeres a través de los videojuegos
}

DOI: $10.46932 / \mathrm{sfjdv} 2 \mathrm{n} 1-018$

Received in: November 1st, 2020

Accepted in: December 30th, 2020

\section{Mar Martínez-Oña}

Doctora en Estudios de las Mujeres y de género, por la Universidad de Granada.

Profesora en ESNE (Escuela Universitaria de Diseño, Innovación y Tecnología), centro adscrito a Universidad Camilo José Cela, Madrid, España.

E-mail: mariadelmar.martinez@esne.es

\author{
Ana M. Muñoz-Muñoz \\ Doctora en Documentación por la Universidad de Granada. \\ Profesora Titular del Departamento de Información y Comunicación y Miembro del Instituto de \\ Investigación de Estudios de las Mujeres y de Género. \\ Universidad de Granada, Granada, España. \\ E-mail: anamaria@ugr.es
}

\section{RESUMEN}

INTRODUCCIÓN: El videojuego, es un producto multimedia de comunicación que entre otros valores, fomenta valores sociales; sin embargo hay que plantearse ¿Qué sucede cuando el usuario/jugador de videojuegos, se debe convertir en el violador más peligroso de la ciudad? Se normaliza entonces, el abuso violento y sexual contra las mujeres, se fomenta y desarrolla una cultura de la violación -Rape cultureque es confirmada y asimilada a través del silencio de la sociedad, quedando así las mujeres sometidas, vejadas y utilizadas.

OBJETIVO: Cuando la violación hacia las mujeres se normaliza e incluso se convierte en un juego, es necesario denunciar determinados videojuegos. Por ello, el objetivo principal de este artículo es identificar y analizar los videojuegos en los cuales se desarrolla la temática de las violaciones femeninas y que llevan implícito como objetivo fundamental las agresiones sexuales. Por tanto, se pretende denunciar como difundir de forma banal este tipo de comportamiento fomenta determinados delitos contra las mujeres, que no deja de ser violencia sexual, violencia machista creada, mantenida y difundida desde una sociedad patriarcal que somete, viola y asesina a las mujeres.

MÉTODOS: A través de las metodologías cualitativa e iconográfica, y usando diversas fuentes de análisis, donde destacamos diversos videojuegos que permitirán identificar sí se fomenta la cultura de la violación a través de su argumento y de sus imágenes.

RESULTADOS: Uno de los primeros videojuegos en los que se representaban violaciones fue La venganza de Custer (EE.UU, 1982), cuyo objetivo era violar a una mujer nativa americana. Pero, lo deplorable es que no se trata de un videojuego aislado, sino que existen otros muchos como RapeLay (Japón, 2006), que anima al jugador a acosar, humillar y violar a una madre y sus dos hijas acechando y violando a tres miembros femeninos de una misma familia. El último los videojuegos lanzado al mercado y que tenía previsto salir a la venta en abril del 2019 es Rape Day, cuyo objetivo principal es asesinar y violar brutalmente a las mujeres, donde se presenta al jugador como un violador y asesino que debe de acosar, violar y matar a mujeres.

CONCLUSIONES: El principal problema es la desensibilización hacia las agresiones sexuales, que se encuentran normalizadas en nuestro entorno histórico-social y son difundidas a través de los medios de comunicación. Esto se traslada también a los videojuegos, donde en algunos, todas las agresiones a las mujeres estarían permitidas, siendo el principal objetivo del juego; por lo que preocupa, pensar que aún 
persisten individuos que disfrutan jugando con estos videojuegos, donde les está permitido someter, violar, e incluso asesinar a mujeres y niñas.

Palabras Clave: Videojuegos, mujeres, jugadores, cultura de la violación, violencia machista.

\section{INTRODUCCIÓN}

La violencia «simbólica» hacia las mujeres la encontramos permanentemente en los videojuegos. Esta situación anómala se normaliza integrándose como parte de una sociedad que relativiza e incluso generaliza la utilización de las mujeres como un objeto sexual. El cuerpo de las mujeres se somete a la voluntad del jugador de videojuego que lo va a utilizar según sus intereses, necesidades o deseos. La mujer queda convertida en un elemento al que el jugador puede pegar, violar, matar y agredir con todo tipo atrocidades necesarias para establecer una relación de poder heredera del patriarcado. Esta situación pone de manifiesto no solo la violencia sexual, sino también la violencia contra las mujeres.

El entorno cultural que fomenta la violencia de género y perpetúa los «mitos de la violación», es lo que se denomina Rape Culture (Cultura de la violación). Este término fue acuñado en la década de los setenta para describir un problema social y cultural donde la violación es aceptada y normalizada debido a pensamientos, creencias, comportamientos y actitudes sociales sobre el género, el sexo y la sexualidad.

Las violaciones femeninas en las sociedades patriarcales se han desarrollado y mantenido a lo largo de la historia como una situación de sometimiento y poder, utilizada incluso como arma de guerra.

[...] cultura patriarcal que legitima el dominio masculino, la violencia como estrategia de relación y sumisión y el sexismo, etc. generan un fenómeno estructural al que Galtung denomina «violencia cultural» y que se está transmitiendo oculta en el proceso de socialización también a través de los videojuegos (Díez \& Terrón, 2014, p. 224).

El tema de la desigualdad entre mujeres y hombres en los videojuegos ha sido analizada por diversos autores como Díez (2004, 2009, 2010, 2014). En uno de sus trabajos centrados en agresiones a mujeres en los videojuegos afirman que con la violación «Se afianza así la socialización en una cultura patriarcal, clave de género explicativa de gran parte de la violencia cultural y estructural de nuestras sociedades» (Díez \& Terrón, 2014, p. 222) denunciando los maltratos constantes hacia las mujeres a través de los videojuegos. Por otra parte Rubio (2003) analiza la diferencia sexual en los videojuegos destacando, además de los estereotipos femeninos, la violencia de género en diversos productos multimedia. Díez et al. (2005) también profundizan en la diferencia sexual en los videojuegos a través de la percepción que tiene el alumando de primaria. La imagen de las mujeres en las carátulas y/o portadas de los videojuegos ha sido estudiada por Urbina, Riera, Ortego y Gibert (2002) quienes identifican los diferentes roles de género femeninos y masculinos y por Bueno y García (2012) que destacan los videojuegos como 
herramienta socializadora y transmisora de valores. Por otra parte, De la Concha (2010) profundiza en la violencia de género en diversas ramas artísticas como cine, literatura y videojuegos y su relación con la construcción cultural del género, y argumenta que la reproducción de los diferentes discursos culturales promueve la violencia física y simbólica.

La relación que existe entre la representación femenina y masculina en los videojuegos ha sido un tema bastante desarrollado, entre estos trabajos destaca el de Fernández (2014) que analiza la ausencia de la presencia femenina en los videojuegos, y su representación. Sobre las representaciones iconografías femeninas en lo videojuegos contribuye la aportación Martínez-Oña y Muñoz-Muñoz (2018) que identifican diferentes iconografías femeninas que aparecen en los mismos.

Aunque existe abundante bibliografía sobre las mujeres en los videojuegos, son escasas las que analizan las escenas de agresiones sexuales femeninas que aparecen en estos. Por ello es necesario profundizar en este tema que servirá de argumento para replantear la igualdad, la educación, los roles, la simbología, la ética e incluso la legalidad de estos videojuegos, en relación con las imágenes y el mensaje que difunden sobre las mujeres, quienes quedan reducidas a meros objetos sexuales «de usar y tirar, e incluso matar», acentuado por la imagen hipersexualizada y cosificada que se ofrece de ellas y que afecta a mujeres y niñas.

\section{OBJETIVO}

El objetivo principal de este estudio es reflexionar sobre la cultura de la violación en los videojuegos a través de la imagen y representación que ofrecen de las mujeres. Y así abordar las razones por las cuales determinadas personas disfrutan o se divierten maltratando y agrediendo sexualmente a las mujeres en los videojuegos.

\section{METODOLOGÍA}

Con la finalidad de alcanzar el citado objetivo se procedió al análisis desde una perspectiva de género de aquellos videojuegos cuya meta es violar a mujeres, para lo que se aplicó una metodología cualitativa para el análisis de la temática y otra iconográfica para el análisis de las imágenes y su significado. La selección se hizo mediante diferentes plataformas de videojuegos y de internet y su identificación con la lectura de las reglas del juego que nos ofrecieron los objetivos y el argumento del mismo. Los tres videojuegos seleccionados se complementan con otros en cuyas acciones se incluyen otro tipo de agresiones que fomentan valores culturales y sociales que la sociedad debe replantearse como pegar, tocar, insultar e incluso matar a mujeres. 
Tabla 1. Clasificación de los videojuegos que fomentan la cultura de la violación. Fuente: Elaboración Propia.

\begin{tabular}{|l|l|l|}
\hline \multicolumn{1}{|c|}{ Violación como objetivo } & \multicolumn{1}{|c|}{ Escenas de violación } & \multicolumn{1}{c|}{ Otras agresiones } \\
\hline La venganza de Custer & Phantasmagoria & Slap Dat \\
\hline RapeLay & Fear Effect & Grand Theft Auto \\
\hline Rape Day & Knights of Xentar & Esclavas del pabellón rojo \\
\hline & Benki Kuosuko & \\
\hline & Sociolotron & \\
\hline
\end{tabular}

A partir de aquí, este estudio se centró en los tres videojuegos más representativos basándonos en su argumentación: La venganza de Custer (EE.UU., 1982), RapeLay (Japón, 2006), Rape Day (EE.UU., 2019). Además estos videojuegos se encontraron y clasificaron otros que aunque el objetivo principal no era la violación en sí de las mujeres, aparecen algunas escenas de violación, tal es el caso de Phantasmagoria, videojuego de 1995;

En Fear Effect una de las protagonistas sufre una violación a cargo de unos tentáculos. En Knights of Xentar hay violaciones explícitas. Slap Dat se presenta con la siguiente leyenda: «Si eres el típico tío que le gusta darle azotes a las tías para ponerlas cachondas este es tu juego». (Díez \& Terrón, 2014, p.225);

o como Grand Theft Auto (GTA), donde las mujeres en ejercicio de la prostitución pueden ser objeto de agresión e incluso asesinato; y otros que demuestran como el maltrato femenino en los videojuegos se ha convertido en una constante e incluso normalizada situación.

La atrocidad y la barbarie hacia las mujeres se vuelve a poner de manifiesto en el videojuego Benki Kuosuko (Fig. 1), donde la sociedad patriarcal vuelve a justificar la tortura y la violación femenina;

En videojuegos descargados de forma gratuita en Internet, como BENKI KUOSUKO el maltrato a la mujer deriva incluso en tortura. Es un juego en el que una mujer japonesa, amordazada y maniatada, se encuentra sentada con las piernas abiertas sobre un retrete y prácticamente desnuda. El jugador, animado por la frase «tienes que hacer gozar a esta japonesa con toda clase de artilugios» puede introducir jeringuillas, huevos, un tarro con leche o pastillas por la vagina y ano de la mujer. El maltrato, la tortura, la violación se presenta como un juego divertido que protagoniza el jugador, bajo el imperativo de «tienes que hacer gozar» a esta mujer. (Díez \& Terrón, 2014, p. 229).

Figura 1. Captura de pantalla del videojuego Benki Kuosuko. Fuente: Díez y Terrón, 2014.

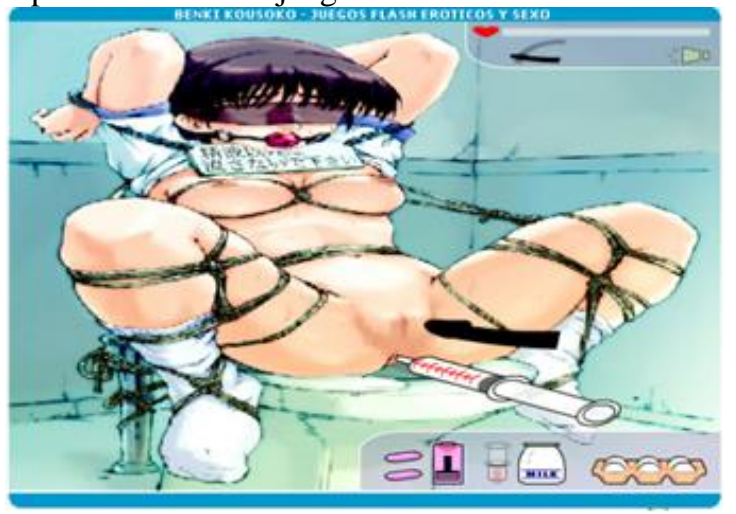


Otro ejemplo es Sociolotron, un juego multijugador que lleva más de 20 años en el mercado, en cuyo argumento aparecen violadores contra mujeres y esclavitud sexual, entre otras muchas cosas.

También, merecen una crítica los denominados juegos "hentai”, es el género del manga/anime que tiene como eje central el sexo entre los personajes, es decir, porno manga donde las mujeres casi en toda la totalidad de los casos son denigradas (Otero, 2017), cosificadas, usadas y agredidas, a esto hay que añadir su imagen como muñecas hinchables plastificadas, delgadas con grandes senos, que en la versión más decente quedan cubiertos con un cubrepezones. Dentro de los videojuegos Hentai destaca Esclavas del pabellón rojo (2006), donde se convierte a una heroína china, Lin Daiyu, en una esclava sexual (Foncillas, 2006) en este videojuego las chicas son vendidas como esclavas sexuales, y además son atadas, juego conflictivo que ocasionó un malestar entre China y Japón.

\section{ANÁLISIS Y DISCUSIÓN}

En el año 1982 aparece uno de los primeros videojuegos en el que el objetivo principal era violar a una mujer, en concreto a una mujer nativa americana, se volvía a utilizar la violación como arma de guerra, hecho que ha sido constante a lo largo de la historia. La plataforma Atari 2600, desarrolló el videojuego La Venganza de Custer (Custer's Revenge). El protagonista del juego, el jugador, representaba al general Custer, quien debía evitar obstáculos para conseguir el objetivo, tener relaciones sexuales no consentidas con una mujer india, que permanecía inmovilizada, atada en un poste llamado "Revenge", si el jugador consigue dicho objetivo recibe los puntos correspondientes. El hecho histórico que se relaciona con este videojuego y de alguna forma la sociedad patriarcal intenta justificar estas violaciones (delito injustificado), es la venganza del General al haber sido derrotado por los indios sioux, y como resarcimiento violará a las mujeres indias, es decir, a las mujeres de sus adversarios.

Semejante atrocidad, quedo reflejada no sólo en el videojuego, sino también en su carátula (Fig. 2) en la cual se destaca a una joven mujer india que responde al código de belleza occidental, con ropajes que dejan al descubierto sus piernas y parte de sus senos y en una actitud placentera aun estando atada al poste, muestra un rostro de placer en la mujer víctima de la violación, no solo se fomenta así las violaciones a las mujeres, sino que se vuelve a justificar el delito con el ¿placer? que le produce a la víctima, la imagen fomenta la idea de que la víctima quisiera serlo, es decir, la falsa y manipulada idea que la víctima quiere ser violada. Debemos hablar entonces de un doble delito de violación, y del fomento y despenalización de ésta.

Este tipo de justificación del delito, también se pone de manifiesto en el videojuego donde podemos apreciar diversos gráficos (Fig. 3 y 4) en el que la víctima se encuentra atada a un cactus, aparece desnuda con grandes pechos, mientras que sonríe ampliamente al ser violada, se evidencia una 
Figura 2. Carátula del videojuego Custer's Revenge. Fuente: Video-juegos pornográficos, 2012.

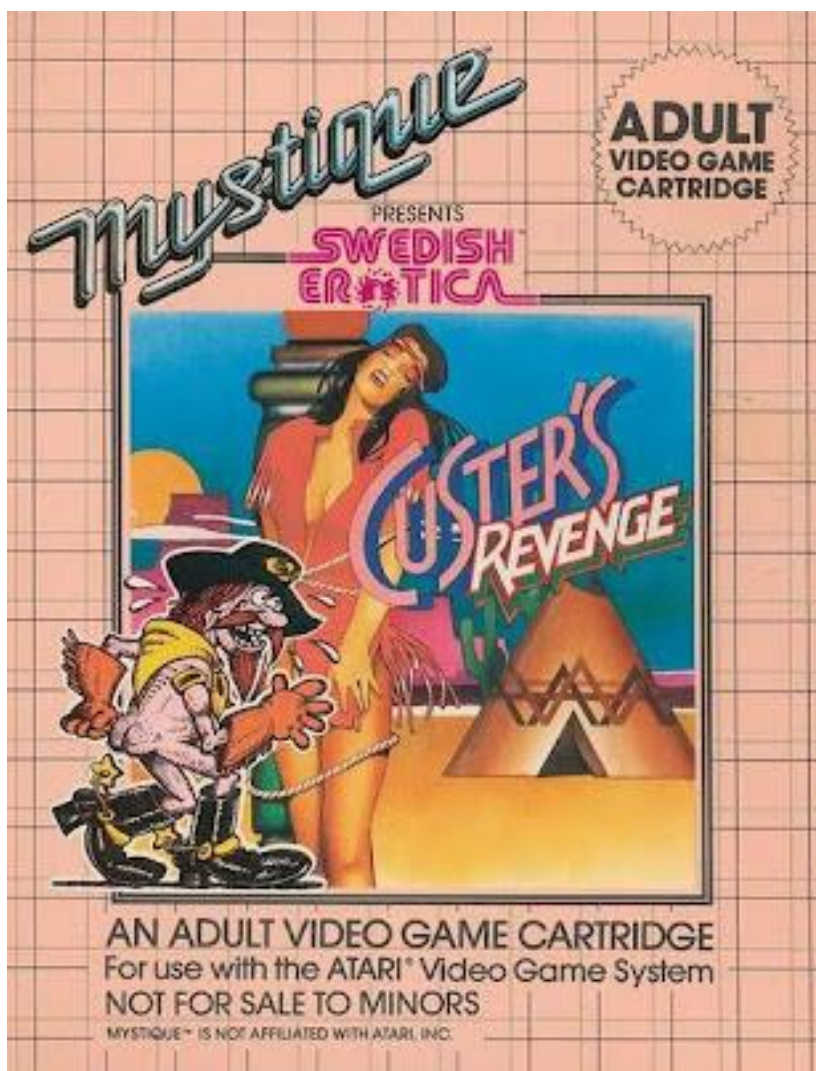

Figuras 3 y 4. Capturas de pantallas del videojuego. Fuente: Video-juegos pornográficos, 2012.

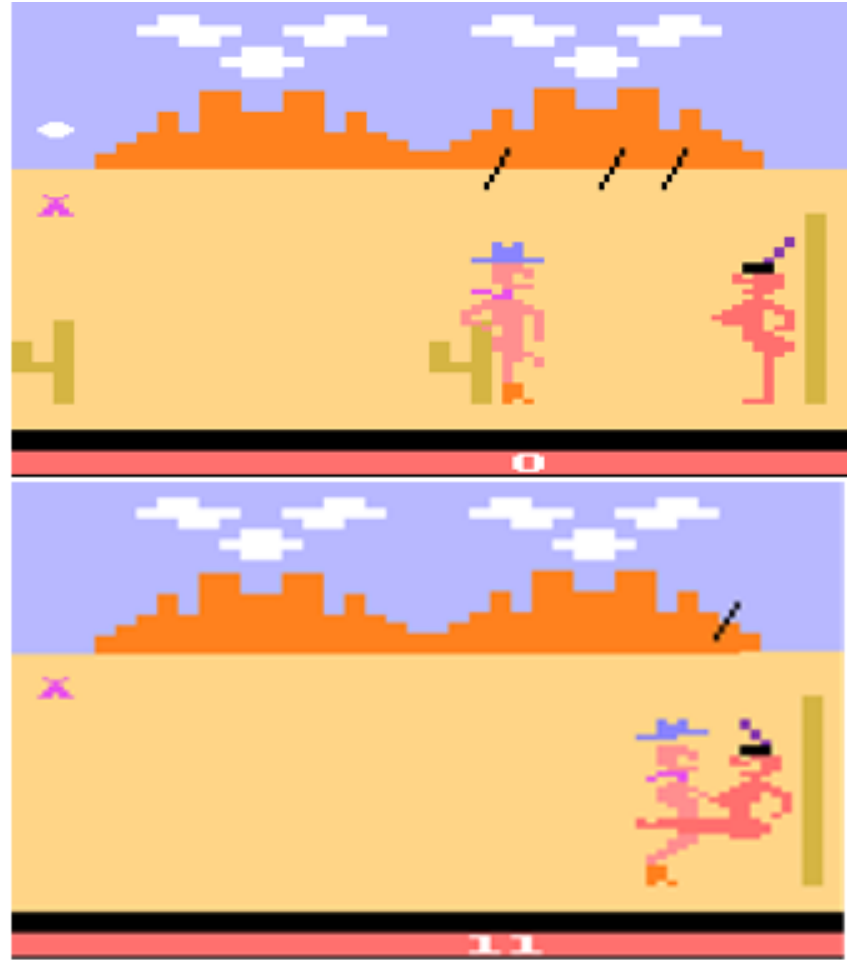


Una crítica destacada, para los videojuegos denominados Hentai, cuya temática se relaciona con la pornografía; en estos juegos, las mujeres y niñas pasan a ser un objeto sexual más. Cuya degradación no será solamente por la temática, sino también por cómo se representan las mujeres.

Dentro de los videojuegos Hentai, resulta muy cruel el videojuego RapeLay (Viola a Lay), donde se anima al jugador a acosar, humillar y violar a una madre y sus dos hijas. Se trata de «[...] un juego de simulación de violaciones que te permite acechar, violar y abusar de una familia de tres mujeres» (Peterson, 2009) no obstante, la sociedad patriarcal intenta justificar esta barbaridad, en este caso se justifica por venganza ya que « [...] el personaje principal está amargado por haber sido arrestado por agresión sexual, le estás permitiendo obtener su «venganza»» (Peterson, 2009).

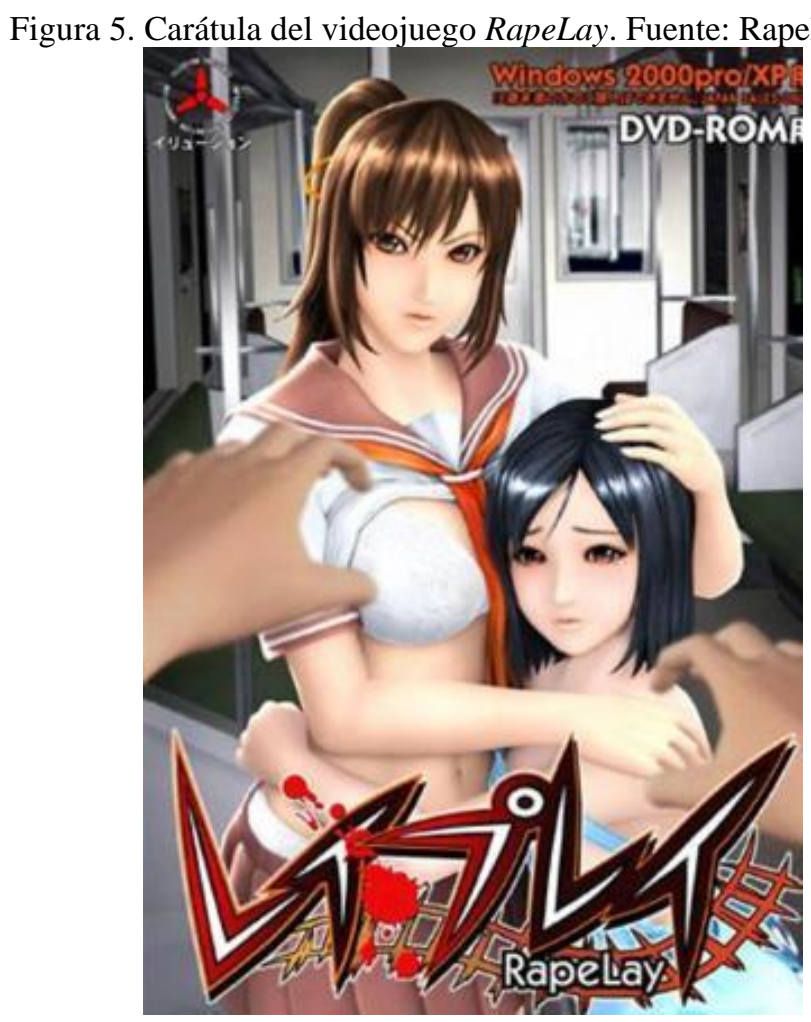

La carátula del videojuego (Fig.4) es suficientemente representativa, en un primer plano aparecen dos chicas abrazadas, en actitudes diferentes, una defendiendo e intentando proteger entre sus brazos a una niña atemorizada ante unas manos masculinas que se dirigen hacia ellas. Las imágenes de las mujeres semidesnudas, de aspecto juvenil con curvas y senos pronunciados, aunque sus escuetos ropajes poseen un matiz más infantil; se presentan ante el voyeur/espectador/jugador/violador, como jóvenes mujeres hipersexualizadas y plastificadas, con referencias iconográficas a los dibujos Manga, donde las mujeres nunca envejecen.

Los gráficos del videojuego, más evolucionados que en otros juegos anteriores, ofrecen una 
imagen más realista de las féminas, donde se las representan con una estética más parecida a muñecas siliconadas, hipersexualizadas y cosificadas (Fig.6); no interesa la mujer como un todo, sino que es suficiente una sola parte, como por ejemplo un seno, para cometer una agresión sexual. Realmente, se trata de una degradación constante, que no favorece la igualdad de género, sino todo lo contrario;

Las mujeres representadas en estos videojuegos aparecen como menores de edad (o al menos se comportan y tienen proporciones físicas de menores), eternas adolescentes - nunca envejecen -, con ojos enormes que muestran una apariencia infantil e ingenua. Los escenarios representados permiten vestir a las chicas en función de fantasías masculinas adolescentes sobresexualizadas: así los escenarios de educación de estos videojuegos permiten vestir a las chicas con uniforme escolar, mientras que los escenarios de fantasía permiten desde trajes de brujas hasta princesas, hadas o «catgirls»; cuando el escenario se ubica en un restaurante, como, por ejemplo, el videojuego Pia Carrot, permite vestir a las chicas con elaborados uniformes de camareras. (Díez \& Terrón, 2014, p. 225).

Figura 6. Captura del pantalla del videojuego RapeLay. Fuente: After Blue Whale Horror, This New Game Is Turning Kids Into 'RAPISTS', 2017.

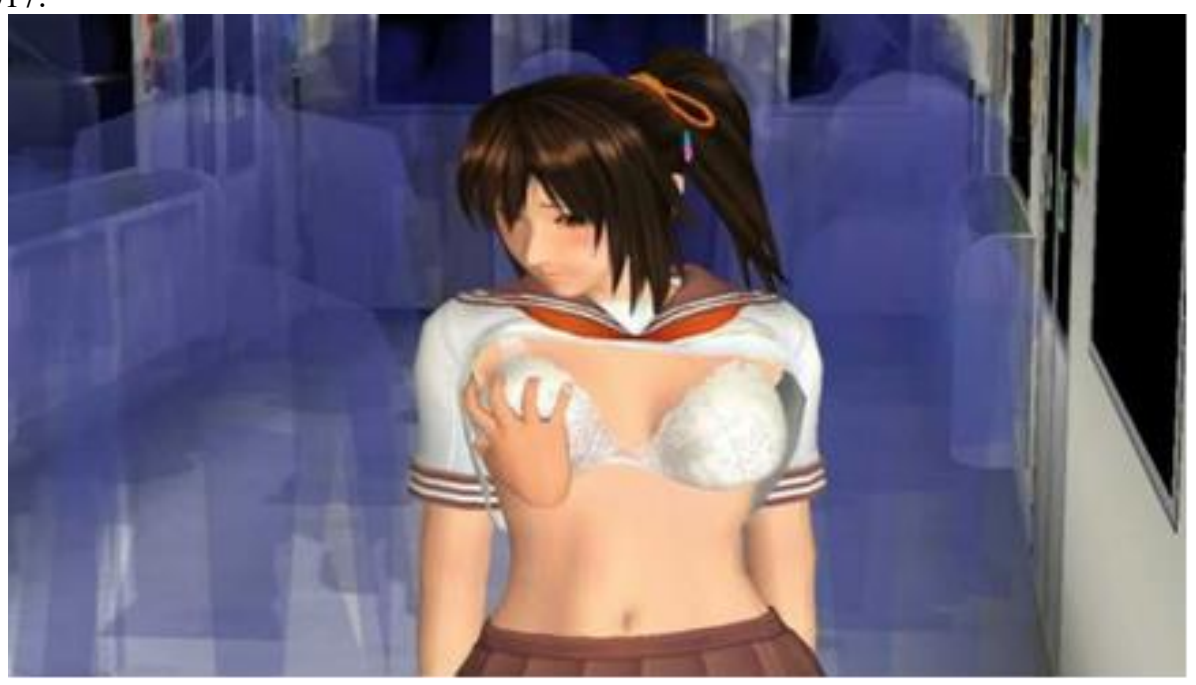

Este juego no sólo fomenta la agresión individual y grupal hacia las mujeres y niñas, sino que también permite otros abusos hacia las mujeres, e incluso deja elegir la forma de violación:

El juego inicia con una adolescente sobre una plataforma del metro. Ella nota que la estás mirando y pregunta. ¿Puedo ayudarle en algo?

Entonces tú, el jugador, puedes elegir el método de agresión.

Con un «click» del ratón, puedes tocarla y levantar su falda. Puedes seguirla en el tren, agrediendo a su hermana y a su madre.

Mientras sigues jugando, otros «amigos» participan y en una serie de escenas gráficas e interactivas, se puede arrinconar a las mujeres y violarlas una y otra vez.

El juego permite que se pueda embarazar a la chica e inducirla a tener un aborto. La razón de la violación, explica el juego, es que la adolescente te acusó de haberla molestado en el tren. Entonces, el motivo es la venganza. («RapeLay» es un videojuego en el que se permite violar por venganza, 2010).

Pero sin duda, uno de los videojuegos que ha causado más polémica recientemente es Rape Day, 
videojuego que tenía previsto salir a la venta en abril de 2019, cuyo objetivo principal es asesinar y violar brutalmente a las mujeres y niñas «El juego se enmarca en una historia de «violencia, agresión sexual, necrofilia e incesto»» (Lluvia de críticas a «Rape Day», un polémico videojuego que consiste en violar y matar a mujeres, 2019). Este videojuego «es descrito como una juego-novela en el que el jugador, un «asesino y violador en serie durante un apocalipsis zombi», «acosa verbalmente, mata y viola mujeres a medida que decide cómo se desarrolla la historia»» (El escándalo de «Rape Day», el videojuego que va de acosar, violar y matar a mujeres, 2019).

Figura 7. Captura de pantalla del videojuego Rape Day. Fuente: El escándalo de «Rape Day», el videojuego que va de acosar, violar y matar a mujeres, 2019.

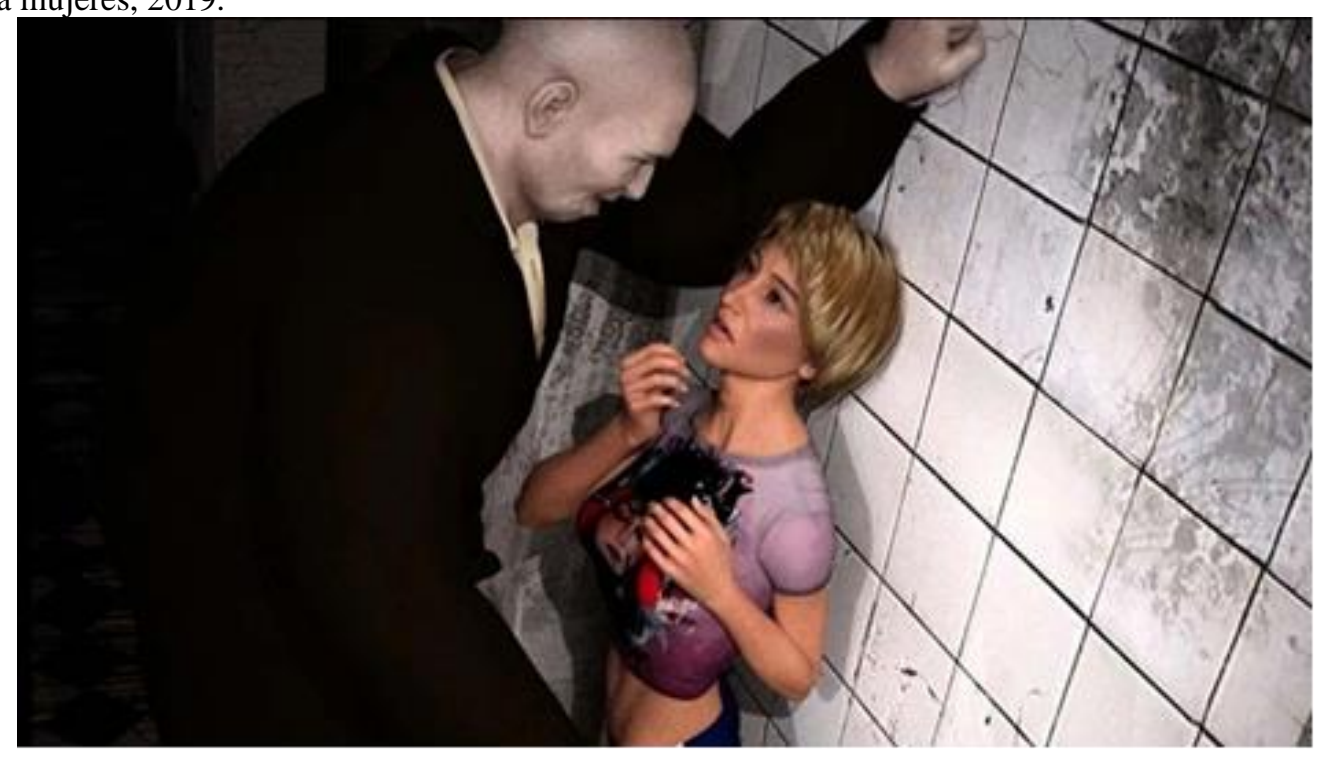

La portada del videojuego (Fig. 8) representa a un grupo de mujeres en ropa interior, a las que persigue el violador/jugador, un primer plano de la boca abierta de éste, se sitúa detrás de las mujeres, como si se las fuera a comer. La imagen de las mujeres nos vuelve a recordar cuerpos delgados y plastificados, con grandes senos, un objeto más para que el asesino/violador/jugador se las pueda comer, que en definitiva es el argumento del juego, violar y asesinar a las mujeres.

Diversas críticas fomentaron que la plataforma Steam, en la cual se había presentado el videojuego, retirará el juego. Sin embargo, se alzaron voces defendiendo este juego, al igual que los videojuegos anteriores se intenta justificar el delito. E incluso actualmente es relativamente fácil, acceder a estos juegos, ya que una parte de la sociedad no lo ve cómo un delito, sino como una diversión, un entretenimiento.

Desk Plant, su desarrollador, afirmaba que el videojuego está destinado a un 4\% de la población general, y que tiene la intención de avanzar con la distribución en otra plataforma (Rape Day: el polémico juego en el que debes violar a mujeres, 2019): 
La moralidad es subjetiva y depende en gran medida de nuestras percepciones y creencias básicas sobre lo que está sucediendo, y aunque creemos que estamos librando grandes guerras contra los malvados villanos, ellos creen lo mismo acerca de nosotros. Las películas que muestran al héroe como un villano son más reales en ese sentido, más completas. Y como la mayoría de la gente, me encanta el porno también. (Frankie, 2019).

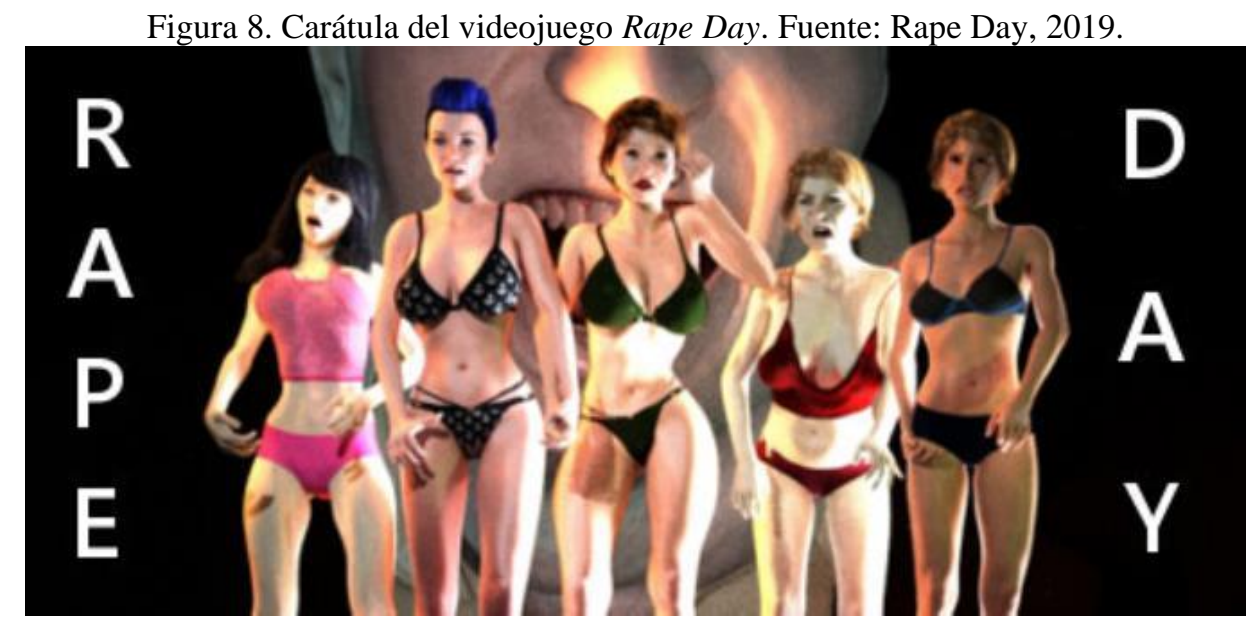

\section{CONCLUSIONES}

Se ha localizado un gran número de videojuegos en los cuales se comenten vejaciones contra las mujeres, quedando representados en ellos, violencia de género contra las mujeres, e incluso videojuegos cuyo objetivo es violar y matar mujeres, un delito que sin embargo no solamente queda inmune sino que es premiado en los videojuegos, silenciado ante la sociedad patriarcal quizás debido a una normalización del tema, algo que la sociedad está acostumbrada a escuchar, y tal vez lo más irracional y grave es el fin de la sociedad patriarcal, al justificar dichas agresiones, bien sea con fines bélicos, de venganza o con la falsa idea del placer femenino, podemos hablar entonces de «Cultura de la violación» y de «Violencia cultural».

Hay que replantear las posibilidades socioeducativas de los videojuegos, los contenidos y valores, tanto implícitos como explícitos, promovidos por los videojuegos y dónde se sitúan sus límites. Para algunos desarrolladores la libertad de expresión permitiría las vejaciones y atrocidades que se pueden realizar a personajes femeninos en los videojuegos, parecen olvidar así derechos fundamentales de las mujeres e incluso Derechos Humanos.

¿Qué pasa cuando el usuario/jugador se convierte en el violador más más peligroso de la ciudad?, debemos de plantear sí esto ¿es divertido? Y sí fomentar las violaciones es delito. No deja de ser una forma de adoctrinación, de normalización de situaciones ilegales, lo cual provoca voces a favor y en contra, puede ser que el jugador no se convierta en la vida real en el violador más peligroso de la ciudad, pero sí tiene las pautas para hacerlo y ha entrenado para ello. Parte de la sociedad e incluso los medios de comunicación señalan a los videojuegos como responsables de problemas sociales. 
A esta situación, se añade la imagen degradada que se ofrece de las mujeres, hipersexuadas, cosificadas, degradadas y dominadas, junto a hombres violadores dominantes. Las imágenes femeninas son simbólicas, al igual que la temática, dentro de la sociedad del siglo XXI en la que el jugador vive rodeado de imágenes, que en un momento dado le pueden permitir dudar entre la imagen real o irreal, lo que es realidad y lo que es ficción.

El desprecio hacia las mujeres, la necesidad de dominio y conquista de la cultura androcéntrica, es un estigma que dificulta llegar a la plena igualdad entre hombres y mujeres. 


\section{BIBLIOGRAFÍA}

After Blue Whale Horror, This New Game Is Turning Kids Into 'RAPISTS' (2017). Stress Buster. Recuperado de https://www.naukrinama.com/stressbuster/rapelay-rape-game/

Bueno Doral, T. R. \& García Castillo, N. (2012). Estereotipos de género y videojuegos: análisis de la imagen de la mujer transmitida en sus carátulas. En Actas del I Congreso Internacional de Comunicación y Género (pp. 1491-1507). Sevilla: Facultad de Comunicación. Universidad de Sevilla.

De la Concha, Ángeles (coord.) (2010). El sustrato cultural de la violencia de género: literatura, arte, cine y videojuegos. Madrid: Síntesis.

Díez Gutiérrez, E. J. (Dir.). (2004). La diferencia sexual en el análisis de los videojuegos. Madrid: CIDEInstituto de la Mujer.

Díez Gutiérrez, E. J. (2009). Videojuegos y sexismos: innovación tecnológica y consolidación de un modelo social desigualitario. Aequalitas: Revista jurídica de igualdad de oportunidades entre mujeres y hombres, (24), 56-68.

Díez Gutiérrez, E. J., Valle Flórez, R.E., García Gorrón, M., Cano González, R, Terrón Bañuelos, E., Castro Fonseca, R. \& Rojo Fernández, J. (2005). La diferencia sexual en el análisis de los videojuegos. Revista Humanidades, Fortaleza, 20(2), 149-154.

Díez Gutiérrez, E. J. \& Terrón Bañuelos, E. (2010). El sexismo en los videojuegos. En F. Teixeira et all. Sexualidade e Educação Sexual: Políticas Educativas, Investigação e Práctica (pp. 241-245). Braga (Portugal): Edições CIEd-Universidade do Minho.

Díez Gutiérrez, E. J. \& Terrón Bañuelos, E. (2014). Sexismo y violencia de género en videojuegos. Exedra: Revista Científica, (1), 222-232.

El escándalo de «Rape Day», el videojuego que va de acosar, violar y matar a mujeres (2019). La Voz de Galicia. Recuperado de https://tinyurl.com/y3yjgnfo

Fernández Vara, Clara (2014). La problemática representación de la mujer en los videojuegos y su relación con la industria. Revista de Estudios de Juventud, (106), 93-108.

Foncillas, A. (2006). De heroína nacional a esclava sexual. Recuperado de https://www.diariocordoba.com/noticias/sociedad/heroina-nacional-esclava-sexual_274119.html Frankie, M.B. (2019). Qué sucede con Rape Day, el videojuego que te pone en el papel de un violador, y qué clase de precedente puede suponer para Steam. Vida Extra. Recuperado de https://tinyurl.com/y3xutm3e

Lluvia de críticas a 'Rape Day', un polémico videojuego que consiste en violar y matar a mujeres (2019). Antena3noticias. Recuperado de https://tinyurl.com/y4przsvw

Martínez-Oña, M. M. \& Muñoz-Muñoz, A. M. (2018). Las mujeres en las iconografías femeninas de los videojuegos. En J. Muñoz Jiménez, S, Martínez Martínez \& B. Peña Acuña (coords.). La realidad audiovisual como nuevo vehículo de comunicación (pp. 255-269). Barcelona: Gedisa. 
Otero, César, 2017. Erotismo Japonés: 7 juegos que subirán la temperatura. MeriStation. Recuperado de https://as.com/meristation/2015/09/16/reportajes/1442404800_148830.html

Peterson, L. (2009). A vicious reflection of society. Recuperado de https://tinyurl.com/y2xm44pc Rape Day: el polémico juego en el que debes violar a mujeres (2019). Público. Recuperado de https://tinyurl.com/y5b34qg4

Rapelay (2012). Yo, me, mi... I, me, my. Recuperado de http://yomemiimemy.blogspot.com/2012/09/rapelay.html

"RapeLay" es un videojuego en el que se permite violar por venganza (2010). Expansión. Recuperado de https://tinyurl.com/y5kbkse3

Rubio Liniers, M. Cruz. (2003). La imagen virtual de la mujer. De los estereotipos tradicionales al ciberfeminismo. Feminismo/s: revista del Centro de Estudios sobre la Mujer de la Universidad de Alicante, (2), 167-182.

Urbina Ramírez, S., Riera Forteza, B., Ortego Hernando, J.L. \& Gibert Martorell, S. (2002). El rol de la figura femenina en los videojuegos. Edutec. Revista Electrónica de Tecnología Educativa, (15). Recuperado de http://edutec.rediris.es/Revelec2/revelec15/santos.htm

Video-juegos pornográficos (2012). Adictamente. Recuperado de https://adictamente.blogspot.com/2012/02/video-juegos-pornograficos.html 